\title{
Demographic structure suggests migration of the sea urchin Paracentrotus lividus in a coastal lagoon
}

\author{
* Catherine Fernandez, Angela Caltagirone ${ }^{\dagger}$ and *Monique Johnson \\ *EqEL, Université de Corse BP52, 20250 Corte, France. 'UMR DIMAR 3, COM, \\ Université de la Méditerranée, Case 901, 13288 Marseille Cedex 9; France.
}

\begin{abstract}
The demographic structure of a population of Paracentrotus lividus living in a coastal Mediterranean lagoon was studied in 1990. Analysis of this structure revealed that the population examined was made up of four distinct cohorts which represented individuals 2, 3, 4 and over 4 years of age. The variability in demographic structure as a function of biotope revealed that sea urchin migration occurred from the pebble area (recruitment area, high sea urchin density and overgrazing facies) towards areas made up of Cymodocea nodosa sea grass beds (growth areas, low density and abundant prefered food). These migrations seem to have been caused by food limitation in the former biotope coupled with a shift in diet in young individuals.
\end{abstract}

Regular sea urchins play an important role in structure and development of benthic plant communities. Indeed, their grazing activity can control plant assemblages (Lawrence, 1975). In addition, several sea urchin species represent important fisheries. Studies dealing with sea urchin population structure and dynamics are of fundamental importance in terms of both the understanding of shallow sublittoral ecosystems and the management of exploited stocks. In the Mediterranean sea, Paracentrotus lividus (Lamarck) has been the subject of a number of studies due to its ecological and economic value (Turon et al., 1995). In the present study, an attempt was made to analyse the demographic structure of a population of P. lividus not subjected to fishing pressures and located in a coastal lagoon (a poorly studied environment). This study was carried out in Urbinu lagoon $\left(42^{\circ} 0.3^{\prime} \mathrm{N}\right.$ $\left.9^{\circ} 28^{\prime} \mathrm{E}\right)$, Corsica, France, Mediterranean. The lagoon contains five biotopes : (1) sand bottoms, (2) pebble bottoms, (3) Cymodocea nodosa (Ucria) Ascherson sea grass beds located at depths of between 0 and $5 \mathrm{~m}$, (4) silt bottoms at depths of between 2 and $8 \mathrm{~m}$ and deep silt bottoms present at depths of over $8 \mathrm{~m}$. Paracentrotus lividus is only present in the first four biotopes.

Sampling was performed using four fixed transects, which were set up so as to run over the four biotopes of interest. All sea urchins present along these transects were measured with a precision of $1 \mathrm{~mm}$ (diameter without the spines). Data collection was carried out monthly from April to August 1990. This represents $132 \mathrm{~m}^{2}$ of C. nodosa sea grass bed, $83 \mathrm{~m}^{2}$ of sand, $85 \mathrm{~m}^{2}$ of silt bottom and $100 \mathrm{~m}^{2}$ of pebble bottom which were examined monthly. Based on the measurement precision, a size class interval of $0.3 \mathrm{~cm}$ was adopted (Fenaux et al., 1987) and the different cohorts were identified using the Bhattacharya method (1967).

Statistical analysis indicates that the demographic structure, in each biotope, did not vary as a function of sampling with months ( $\chi^{2}$-tests, $P>0.05$ for each biotope), thus allowing the data to be pooled. Bhattacharya analysis, revealed that there were four cohorts present within the lagoon (Figure 2A). Based on growth models proposed for P. lividus (Fenaux et al., 1987; Turon et al., 1995), the individuals belonging to cohort 1 would be approximately 2 years old, those of cohorts 2, 3 and 4 approximately 3, 4 and over 4-y old, respectively. Demographic structure for each biotope (Figures 2, B-E) revealed that (cohort 1 was present in the pebble and silt biotopes, cohort 2 was found in the pebble, silt and sand biotopes, as was cohort 3, whereas cohort 4 was present within the sea grass beds. The overall tendency was towards an increase in mean sea urchin diameter as one proceeds from the pebble biotope towards the $C$. nodosa biotope.

The data would tend to suggest a migration from the pebble to the seagrass areas and would thus involve the passing of the sea urchins over the silt and sand bottoms that separate these two biotopes. A hypothesis concerning the migration of urchins has already been proposed (Francour \& Paul, 1987; Guillou \& Michel, 1993) and would appear to occur from recruitment areas towards growth areas, due perhaps to a change in diet in young individuals (Guillou \& Michel, 1993). In Urbinu lagoon, the small-sized individuals are mostly found in the pebble areas, which are thus probably the recruitment sites of the lagoon. Indeed, these sites offer all of the characteristics necessary for the recruitment and development of young individuals including shelter and the presence of coralligenous and filamentous algae (Verlaque, 1984; Rowley, 1989). Although the pebble biotopes appear to provide both food and shelter to the young individuals, the fleshy erect algae, which make up the diet of the adult individuals (Verlaque, 1984), are rare on the pebble bottoms (personal observation) and the density of the sea urchins on these bottoms $\left(67\right.$ ind $\mathrm{m}^{-2}$ ) further accentuates the sparseness of the macrophytes due to overgrazing. Adult sea urchins living here exhibit scavenger behaviour (53\% mineral fraction, 5.1\% dead plant material and $19.1 \%$ animal carcasses) with macroalgea representing only $8.1 \%$ of the diet. It is therefore probable that individuals will leave the recruitment area to seek a more favourable area for fattening, one in which food is not a limiting factor. Only C. nodosa sea grass beds provide such an abundant food source, this phanerogam being considered to be a the 'preferred' food of P. lividus (Traer, 1980). In fact, this biotope only harbours large individuals possessing the morphological characteristics of urchins living in a favourable environment (Fernandez \& Boudouresque, 1997).

The migration between the pebble and sea grass areas would require migration over great distances on silt and/or sandy bottoms. The presence of sea urchins in these last biotopes proves that such a migration is possible. The straight line distances covered daily by $P$. lividus are in the order of $0.5-2 \mathrm{~m}$ per day (Dance, 1987). Generally, the distance covered increases as a function of the distance separating the sea urchins from an 


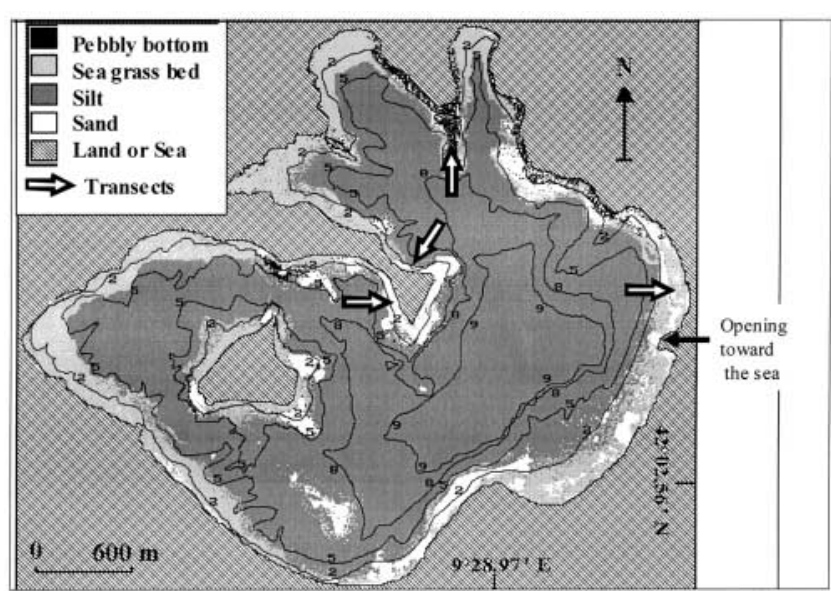

Figure 1 Biotopes and bottom types present in Urbino lagoon.
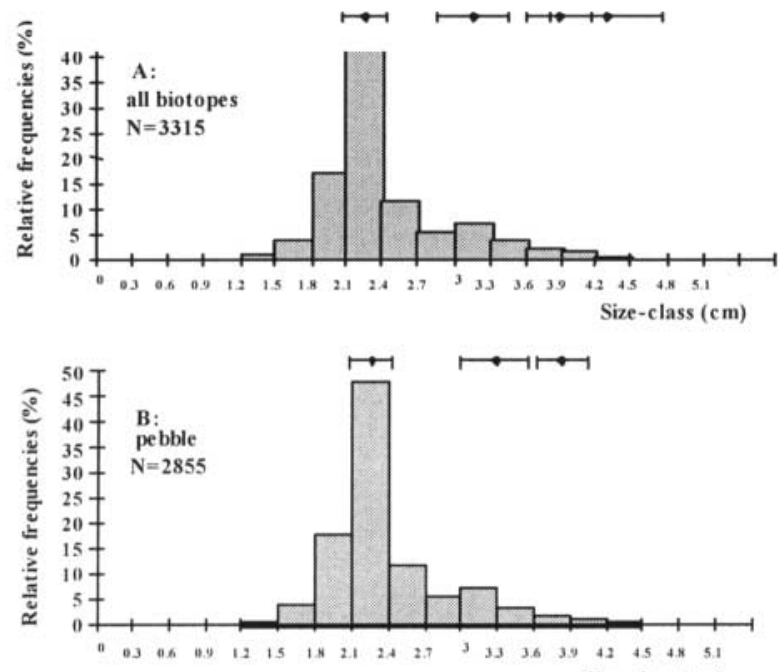

Size-class $(\mathrm{cm})$
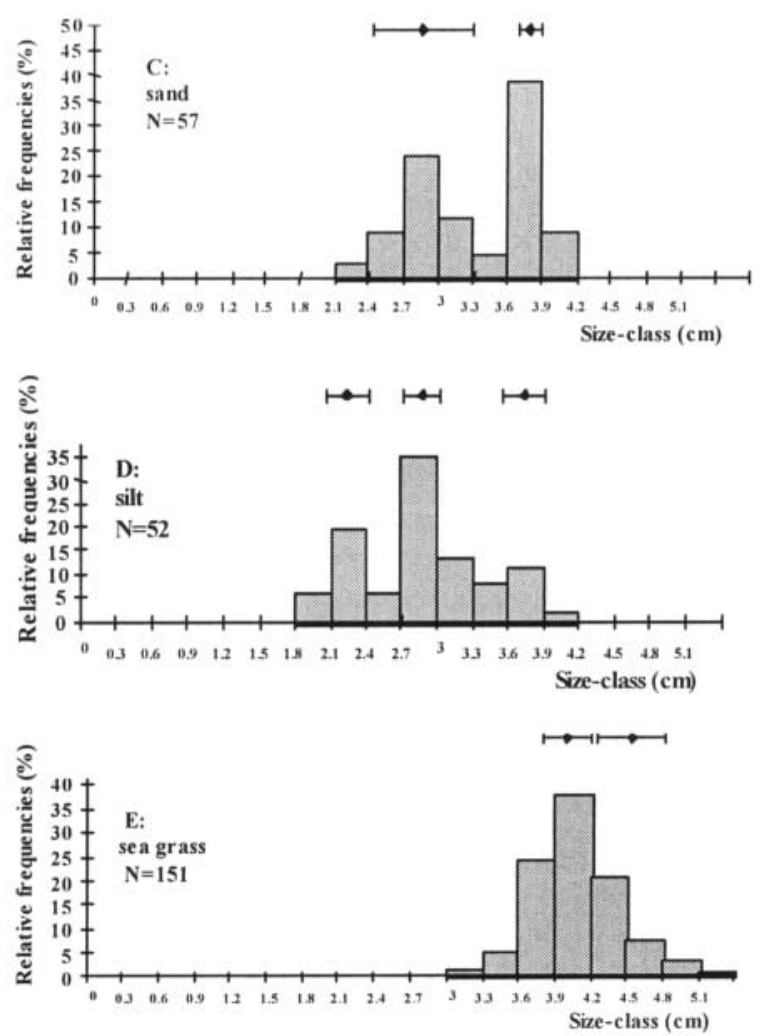

Figure 2 Demographic structure of Paracentrotus lividus in Urbino lagoon (at the top: mean size and confidence interval of the cohorts). abundant or prefered food: the sea urchins migrate in order to seek out new food resources (Mattison et al., 1977). In the present study, it is suggested that the sea urchins move through areas with limiting trophic resources (silt and sand) in order to reach more favourable areas (sea grass beds). At a displacement rate of $2 \mathrm{~m} \mathrm{day}^{-1}$, a sea urchin would require several months to cover the distance separating the pebble areas from the numerous sea grass beds.

Alternative explanations of the urchin distribution, however, may involve factors such as diferrential mortality, episodic recruitment and a possible change in size/age relationships as a function of the biotope.

In the present study, the migration of a portion of the P. lividus population inhabiting a lagoon was suggested. It is clear that both a long-term study of demographic structure and a study of the actual sea urchin migration are necessary if the migration hypothesis is confirmed.

\section{REFERENCES}

Bhattacharya, C.G., 1967. A single method of resolution of a distribution into gaussian components. Biometrics, 123, 11-25.

Dance, C., 1987. Patterns of Activity of the sea urchin Paracentrotus lividus in the bay of Port-Cros (Var, France, Mediterranean). P.S.Z.N.I.: Marine Ecology, 8, 131-142.

Fenaux, L., Etienne, M. \& Quelart G., 1987. Suivi écologique d'un peuplement de Paracentrotus lividus (Lamarck) dans la baie de Villefranche sur mer (France). In Colloque international sur Paracentrotus lividus et les oursins comestibles, (ed. C.F. Boudouresque), pp. 187-197. Marseille: GIS Posidonie.

Fernandez C., Boudouresque C. F., 1997. Phenotypic plasticity of Paracentrotus lividus (Echinoidea: Echinodermata) in a lagoonal environment. Marine Ecology Progress Series, 152, 145-154.

Francour, P. \& Paul, O., 1987. Densité, biomasse et relation taillepoids chez l'oursin Psammechinus microtuberculatus de l'herbier à Posidonia oceanica de Port-Cros (France, Méditerranée). In Colloque international sur Paracentrotus lividus et les oursins comestibles, (ed. C. F. Boudouresque), pp.169-181. Marseille: GIS Posidonie.

Guillou, M. \& Michel, C., 1993. Reproduction and growth of $\begin{gathered}\text { Guillo } \\ \text { and } \\ \text { Nichd }\end{gathered}$ Sphaerechinus granularis (Echinodermata: Echiniodea) in 1993, southern brittany. Fournal of the Marine Biological Association of $\underset{\text { or }}{\text { brtany }}$ the United Kingdom, 73, 179-193.

Lawrence, J.M., 1975. On the relationships between marine plants and sea-urchins. Oceanography and Marine Biology Annual Revue 13, 213-286.

Mattison, J.E., Trent, J.D., Shanks, A.L., Akin, T.B. \& Pearse, J.S., 1977. Movement and feeding activity of red sea urchins (Strongylocentrotus franciscanus) adjacent to kelp forest. Marine Biology, 39, 25-30.

Rowley, R.J., 1989. Settlement and recruitment of sea urchin (Strongylocentrotus sp.) in a sea urchin barren ground and a kelp bed: are populations regulated by settlement or post-settlement processes. Marine Biology, 100, 485-494.

Traer, K., 1980. The consumption of Posidonia oceanica Delile by echinoids at the isle of Ischia. In Echinoderms: present and past, (ed. M. Jangoux), pp. 241-244. Rotterdam: A.A. Balkema.

Turon, X., Giribet, G., Lopez, S. \& Palacin, C., 1995. Growth and population structure of Paracentrotus lividus (Echinodermata: Echinoidea) in two contrasting habitats. Marine Ecology Progress Series, 122, 193-204.

Verlaque, M., 1984. Biologie des juvéniles de l'oursin herbivore Paracentrotus lividus (Lamarck): sélectivité du broutage et impact de l'espèce sur les communautés algales de substrat rocheux en Corse (Méditerranée, France). Botanica marina, 27, 401-424. 